\title{
ACTIVATED CARBON FROM BAMBOO (Bambusa vulgaris) FOR METHYLENE BLUE REMOVAL: PREDICTION TO THE ENVIRONMENT APPLICATIONS
}

\section{CARVÃO ATIVADO A PARTIR DE BAMBU (Bambusa vulgaris) PARA REMOÇÃO DE AZUL DE METILENO: PREDIÇÕES PARA APLICAÇÕES AMBIENTAIS}

\author{
Gregório Mateus Santana ${ }^{1}$ Roberto Carlos Costa Lelis ${ }^{1}$ Juarez Benigno Paes ${ }^{2}$ Rayssa de \\ Medeiros Morais ${ }^{1}$ Cláudio Rocha Lopes ${ }^{3}$ Carlos Roberto de Lima ${ }^{4}$
}

\begin{abstract}
Activated carbon (AC) is an essential product for the removal of environmental contaminants, but the high production costs limit its use. In this work, $\mathrm{AC}$ was produced from bamboo through simultaneous direct physical-chemical activation (by using phosphoric acid and water steam), at $500{ }^{\circ} \mathrm{C}$ for 1 hour, to evaluate its adsorption effectiveness for methylene blue dye (MB). Adsorption kinetic and equilibrium studies at batch system were realized at room temperature (to evaluate the adsorption influence of the MB dye over the produced AC) and the Langmuir and Freundlich isotherms systems were selected for understanding the adsorption process. The produced AC showed a relatively high value of surface area equal to $1354.42 \mathrm{~m}^{2} . \mathrm{g}$ ${ }^{1}$. The required contact time for the MB to reach equilibrium was 12 hours. The adsorption performance was better delineated by the Langmuir isotherm, which maximum adsorption capacity was of $374.75 \mathrm{mg} . \mathrm{g}^{-1}$. In addition, the $\mathrm{R}_{\mathrm{L}}$ dimensionless factor reveled the favorable nature of the adsorption process in the used conditions. The results obtained in this study recommend the use of the produced AC from bamboo in the treatment of the water contaminated by the MB dye, foremost in higher concentrations than limits admitted by the legislation. Finally, complementary researches must be conducted to improve, even more, the quality of the produced material.
\end{abstract}

Keywords: physical-chemical activation; adsorption; water treatment.

\section{RESUMO}

O carvão ativado (CA) é um produto essencial para remoção de contaminantes ambientais, entretanto os altos custos de produção limitam seu uso. Neste trabalho, foi produzido CA a partir de bambu mediante ativação físico-química simultânea direta (utilizando ácido fosfórico e vapor d'água), a $500{ }^{\circ} \mathrm{C}$ por 1 hora, para avaliar sua eficácia na adsorção do corante azul de metileno (AM). Estudos cinéticos e de equilíbrio de adsorção em sistema batelada foram realizados em temperatura ambiente (para avaliar a influência da adsorção do corante AM sobre o CA produzido) e os modelos de isotermas de Langmuir e de Freundlich foram selecionados para entender o processo de adsorção. O CA produzido apresentou um valor relativamente alto de área superficial igual a $1354,42 \mathrm{~m}^{2} \mathrm{~g}^{-1}$. O tempo de contato preciso para o AM atingir o equilíbrio foi de 12 horas. O desempenho da adsorção foi melhor delineado pelo modelo dado pela isoterma de Langmuir, cuja capacidade máxima de adsorção foi de $374,75 \mathrm{mg} \mathrm{g}^{-1}$. E o fator adimensional $\mathrm{R}_{\mathrm{L}}$ revelou a natureza favorável do processo de adsorção nas condições realizadas. Os resultados obtidos neste estudo

1 Engenheiro Florestal, Dr., Programa de Pós-Graduação em Ciências Ambientais e Florestais, Instituto de Florestas, Universidade Federal Rural do Rio de Janeiro, BR 465, km 07, CEP 23890-000, Seropédica (RJ), Brasil. gregorioengflorestal@gmail.com / lelis@ufrrj.br / rayssaengflorestal@gmail.com

2 Engenheiro Florestal, Dr., Departamento de Ciências Florestais e da Madeira, Universidade Federal do Espírito Santo, Av. Gov. Lindemberg, 316, CEP 29550-000, Jerônimo Monteiro (ES), Brasil. jbp2@uol.com

3 Engenheiro Metalúrgico, Dr., Escola de Engenharia Industrial Metalúrgica de Volta Redonda, Universidade Federal Fluminense, Av. dos Trabalhadores, 420, CEP 27255-125, Volta Redonda (RJ), Brasil. claudio@metal. eeimvr.uff.br

4 Engenheiro Florestal, Dr., Unidade Acadêmica de Engenharia Florestal, Universidade Federal de Campina Grande, Av. Universitária, s/n, Santa Cecília, CEP 58708-110, Patos (PB), Brasil. crlima16@hotmail.com

Recebido para publicação em 25/02/2017 e aceito em 31/07/2017 
recomendam o uso do CA produzido a partir de bambu no tratamento de água contaminada pelo corante $\mathrm{AM}$, mormente em concentrações maiores que os limites permitidos pela legislação. Finalmente, pesquisas complementares devem ser realizadas para aprimorar, ainda mais, a qualidade do material produzido.

Palavras-chave: ativação físico-química; adsorção; tratamento de água.

\section{INTRODUCTION}

According to the United Nations, in 2030 half of the world's population will live in water shortage areas (NAÇÕES UNIDAS, 2016), a situation already experienced in several countries in the world. That account presages the diversified search for new technologies that allows the decontamination/reuse of the water, aiming, for example, for the dye removal from water bodies.

Alluding to the dyes, these correspond to a multiplicity of organic compound introduced in the water, especially through wastes of textile, paper, pharmaceutical and tannery factories, which causes significant problems to the environment, such as the increase of toxicity and lower oxygen demand, besides the light penetration reduction in some environments, which acts in the photosynthetic phenomena (BULUT; AYDIN, 2006; CARMEN; DANIELA, 2012; MEZOHEGYI et al., 2012).

That been said, adsorption Kinetic and equilibrium studies are being executed in search for comprehending the dyes adsorption mechanisms. Among them, the methylene blue stands out, which lies as an extensively researched and studied dye in adsorption on solids, repeatedly presented as a model compound to be followed in adsorption studies of organic compounds from aqueous solutions (HAMEED; DIN; AHMAD, 2007; AVELAR et al., 2010; COUTO et al., 2012; BORGES et al., 2016).

In this scenario, the activated carbon appears as a very promising technology for the dye removal from an aqueous solution (AVELAR et al., 2010; PEZOTI JR et al., 2016). A promising technology because, in theory, nowadays, the activated carbon is one of the main adsorbents researched for the removal of contaminants in the water (NJOKU; FOO; HAMEED, 2013; NJOKU et al., 2014).

Even not being the only adsorbent in this intent, search for this product has wildly increased for its high surface area, which facilitates the adsorption capacity, mainly when used for separating contaminants in a purification process, having an important part in chemical, pharmaceutical and food industries, which makes an increasing coverage breadth of this product in the world consumption (HAYASHI et al., 2002; AVELAR et al., 2010; ROMERO-ANAYA et al., 2014; CESKAA, 2016), because of the increase of the pollution levels, health problems and increasing governmental regulations that claims for anti-pollution alternatives (CESKAA, 2016).

The search and necessity of this material is reflected on the global market, with the AC in 2015 being evaluated in 2.7 billion dollars, boosted mainly by the USA and the Asia-Pacific region. There are talks of the probability of this value to reach 5.1 billion dollars until 2021 (CESKAA, 2016).

As a profusely porous material, the activated carbon is originated from the activation process, that involves the thermic and/or chemical treatment of the raw material, that, in the present study, is the bamboo, although the lack of vast raw materials in this regard conducted the researchers to find less costly new precursors for AC preparation (HAMEED; DIN; AHMAD, 2007; HAMEED; EL-KHAIARY, 2008; AVELAR et al., 2010; COUTO et al., 2012; NJOKU; FOO; HAMEED, 2013; BARBOSA et al., 2014; BORGES et al., 2016; LINHARES; MARCÍLIO; MELO, 2016; PEZOTI JR et al., 2016). 
In the AC production process physical or chemical activating agents are used, being responsible for promoting the porosity increase and thus the surface area increase. The main activating agents used on the AC production are water steam, carbon dioxide, zinc chloride, and phosphoric acid. About the activation processes, two are applied: the physical or chemical activation. The physical activation is the one that revolves around the synthesis of the raw material at elevated temperatures that varies from 700 to $1000{ }^{\circ} \mathrm{C}$ and the use of a physical activating agent such as water steam or carbon dioxide; while the chemical activating covers the synthesis of the raw material at lower temperatures that varies from 400 to $700{ }^{\circ} \mathrm{C}$ in which, in a previous step of the thermal treatment, the raw material is impregnated with a concentrated solution of an activating agent such as zinc chloride and phosphoric acid. Nowadays, both of the process can be used concomitantly.

Next to this, there are the connected variables of the AC production process as activation temperature, residence time and proportion of the used activating agent proportion must be considered, because they have influence over the final processing costs and becoming a competitive differential. Therefore, when the process variables are enhanced and the quality is assured, the production costs are reduced.

According to the stated, in order to contribute to the enhancement of AC that can be used to water treatment, this article discusses the production of these materials, that have the bamboo as raw material, and analyses the results of their applications from kinetic and adsorption equilibrium studies for the MB dye.

\section{MATERIAL AND METHODS}

\section{Activated carbon production and BET surface area}

The specie herein used, Bambusa vulgaris, came from two-year-old plantations from the Celulose e Papel de Pernambuco S.A. (CEPASA) of the Grupo Industrial João Santos, located in Jaboatão dos Guararapes, Pernambuco state, Brazil. The raw material was impregnated with a $\mathrm{H}_{3} \mathrm{PO}_{4}$ concentration solution at 2:1 (m:m), under agitation at $80{ }^{\circ} \mathrm{C}$ in a magnetic shaker (Fisatom, São Paulo, Brasil) for $2 \mathrm{~h}$. Then, it was dried at a conventional oven at $103 \pm 2{ }^{\circ} \mathrm{C}$ for $24 \mathrm{~h}$ and thereon activated at a CHINO rotating electric oven (Takabayashi Rica, RS-S model, Japan), containing a tubular reactor (93 mm internal diameter and $900 \mathrm{~mm}$ length), an electric boiler and an attached dewar container with $\mathrm{N}_{2}$.

The activation process was made effective at a final temperature of $500{ }^{\circ} \mathrm{C}$, with a $10{ }^{\circ} \mathrm{C} \cdot \mathrm{min}^{-1}$ heating rate, residence time of 1 hour with water steam flux of $100 \mathrm{~mL} \cdot \mathrm{min}^{-1}$ and $\mathrm{N}_{2}$ flux of $80 \mathrm{~mL} \cdot \mathrm{min}^{-1}$. When the process ended, the oven was turned off, the $\mathrm{N}_{2}$ flux maintained until $300{ }^{\circ} \mathrm{C}$ and the $\mathrm{AC}$ taken off the oven after $150^{\circ} \mathrm{C}$ (Figure 1). The obtained $\mathrm{AC}$, called $\mathrm{H}_{3} \mathrm{PO}_{4} / \mathrm{H}_{2} \mathrm{O} \mathrm{AC}$, was washed with distilled water, alternately hot and cold, until neutral $\mathrm{pH}$. After the washing, it was dried at kiln at $103 \pm 2{ }^{\circ} \mathrm{C}$ for $24 \mathrm{~h}$.

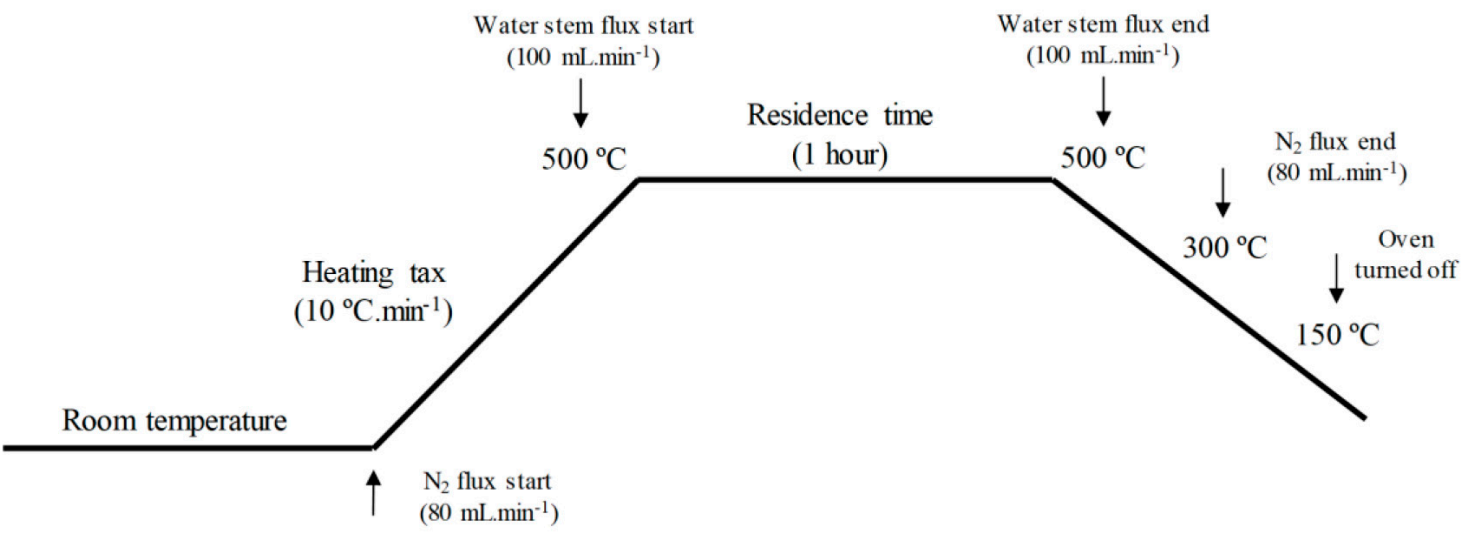

FIGURE 1: Heating ramp used in the activation process.

FIGURA 1: Rampa de aquecimento utilizada no processo de ativação. 
The BET surface area was made with the gaseous step adsorption data obtained using an automatic adsorption system (Autosorb-6, Quantachrome Corporation, USA), after the sample was vacuum-degasified at $250{ }^{\circ} \mathrm{C}$. The method employs the nitrogen $\left(\mathrm{N}_{2}\right)$ adsorption technique at $77 \mathrm{~K}$ and is based on the BET Brunauer, Emmett and Teller (SKAAR, 1988; MEDEIROS, 2008) works, as represented in Eq. (1).

$$
V_{a}=\frac{V_{m} \times C \times P}{\left(P_{0}-P\right)\left[1+(C-1)\left(\frac{P}{P_{0}}\right)\right]}
$$

where: $\mathrm{V}_{\mathrm{a}}=$ adsorbed gas amount at $\mathrm{P}$ pressure $(\mathrm{mL}) ; \mathrm{V}_{\mathrm{m}}=$ adsorbed gas amount when all surface is covered by a monomolecular layer $(\mathrm{mL}) ; \mathrm{C}=$ Surface interaction energy constant and $\mathrm{P}_{0}=$ gas saturation pressure.

\section{Evaluations for applications of the studied activated carbon and adsorbate}

Aiming to evaluate the $\mathrm{H}_{3} \mathrm{PO}_{4} / \mathrm{H}_{2} \mathrm{O}$ AC use in the water treatment, adsorption studies were made with the amorphous natured cationic dye methylene blue, produced by Proquimios Comércio e Indústria Ltda. (Rio de Janeiro, Brazil), with 319.85 g. mol$^{-1}$ molar mass (Figure 2). All the solutions were prepared with distilled water and obtained by dilution of the initial solution of MB with a $1000 \mathrm{mg} . \mathrm{L}^{-1}$ concentration.<smiles></smiles>

FIGURE 2: Chemical structure of methylene blue (MB).

FIGURA 2: Estrutura química do azul de metileno (AM).

\section{Effect of the contact time}

The effect of the adsorbate/adsorbent contact time was obtained by using $10 \mathrm{mg}$ of $\mathrm{H}_{3} \mathrm{PO}_{4} / \mathrm{H}_{2} \mathrm{O}$ $\mathrm{AC}$ and $10 \mathrm{~mL}$ of methylene blue solutions at a $50 \mathrm{mg} \cdot \mathrm{L}^{-1}$ concentration, which were put in a set of $20 \mathrm{~mL}$ containers that were sealed shut and then kept under rotation in a shaker (SL 221, SOLAB, São Paulo, Brazil), with a $100 \mathrm{rpm}$ rotation control and room temperature (the analysis was made in duplicate and an average value of the results were taken).

At predetermined intervals of $1,3,6,12$ and $24 \mathrm{~h}$, aliquots of the solutions were taken and their concentrations determined by using the characteristic wavelength $(\lambda)$ of the MB dye, $\lambda=665 \mathrm{~nm}$. The UVVIS spectrophotometer (Shimadzu, UV-mini 1240, Japan) were used to determine the dye concentrations. The MB amount that was adsorbed in a t, $\mathrm{q}_{t}\left(\mathrm{mg}_{\mathrm{g}} \mathrm{g}^{-1}\right)$ time was calculated according to the Eq. (2).

$$
q_{t}=\frac{\left(C_{0}-C_{t}\right) x V}{m}
$$

where: $\mathrm{C}_{0}$ and $\mathrm{C}_{\mathrm{t}}=$ represent, respectively, the dye concentrations at liquid phase, initial and in the predetermined time intervals (mg. $\left.\mathrm{L}^{-1}\right) ; \mathrm{V}=$ adsorbate volume (L); and $\mathrm{m}=$ adsorbent mass $(\mathrm{g})$. 


\section{Adsorption isotherm}

For this essay, the same initial procedures described for the adsorption kinetic study were made, providing that the $20 \mathrm{~mL}$ container set were kept under rotation in a shaker for $24 \mathrm{~h}$, at room temperature, until they reach the adsorption equilibrium. After this period, they were removed from the shaker, the samples were filtered and the equilibrium concentration determined in the UV-VIS spectrophotometer, in absorbance punctual analysis $(\lambda=665 \mathrm{~nm})$. Calibration curve were made with methylene blue solutions at 25, 50, 100, 250, 500 and $1000 \mathrm{mg} . \mathrm{L}^{-1}$ concentrations. The adsorbed adsorbate (methylene blue) amount per adsorbent gram $\left(\mathrm{H}_{3} \mathrm{PO}_{4} / \mathrm{H}_{2} \mathrm{O} \mathrm{AC}\right), \mathrm{q}_{\rho \text { คn }}$ (mg.g $\left.\mathrm{g}^{-1}\right)$, was calculated according to the Eq. (3).

$$
q_{e q}=\frac{\left(C_{0}-C_{e q}\right) x V}{m}
$$

where: $\mathrm{C}_{0}$ and $\mathrm{C}_{\mathrm{eq}}=$ represent, respectively, the initial and at balance concentrations (mg. $\left.\mathrm{L}^{-1}\right) ; \mathrm{V}=$ the adsorbate volume $(\mathrm{L})$ and $\mathrm{m}=$ the adsorbent mass $(\mathrm{g})$.

\section{RESULTS AND DISCUSSION}

\section{BET surface area}

The obtained $\mathrm{H}_{3} \mathrm{PO}_{4} / \mathrm{H}_{2} \mathrm{O}$ AC presented BET surface area $\left(\mathrm{S}_{\mathrm{BET}}\right)$ equal to $1354.42 \mathrm{~m}^{2} \cdot \mathrm{g}^{-1}$, which compares to other adsorbents found in literature as show in Table 1.

TABLE 1: Surface area $\left(\mathrm{S}_{\mathrm{BET}}\right)$ obtained for various adsorbents.

TABELA 1: Área superficial $\left(\mathrm{S}_{\mathrm{BET}}\right)$ obtida para vários adsorventes.

\begin{tabular}{|c|c|c|c|c|}
\hline \multirow{2}{*}{ Raw material } & \multicolumn{2}{|c|}{ Used processes } & \multirow{2}{*}{$\mathrm{S}_{\mathrm{BET}}\left(\mathrm{m}^{2} \cdot \mathrm{g}^{-1}\right)$} & \multirow{2}{*}{ Reference } \\
\hline & Carbonization & Activation & & \\
\hline Bamboo & - & $\mathrm{H}_{3} \mathrm{PO}_{4} / \mathrm{H}_{2} \mathrm{O}, 500{ }^{\circ} \mathrm{C}, 1 \mathrm{~h}$ & 1354.42 & This work \\
\hline Bamboo & $700^{\circ} \mathrm{C}, 1 \mathrm{~h}$ & $\mathrm{KOH} / \mathrm{CO}_{2}, 850^{\circ} \mathrm{C}, 2 \mathrm{~h}$ & 1896.00 & Hameed et al. (2007) \\
\hline Bamboo & $500^{\circ} \mathrm{C}, 1 \mathrm{~h}$ & $\mathrm{~K}_{2} \mathrm{CO}_{3} / \mathrm{CO}_{2}, 850^{\circ} \mathrm{C}, 2 \mathrm{~h}$ & 1724.00 & Hameed and El-Khaiary (2008) \\
\hline Bamboo & - & $\mathrm{H}_{3} \mathrm{PO}_{4} / \mathrm{H}_{2} \mathrm{O}, 500{ }^{\circ} \mathrm{C}, 1 \mathrm{~h}$ & 1196.30 & Santana et al. (2017) \\
\hline Piassava & - & $\mathrm{ZnCl}_{2}, 500^{\circ} \mathrm{C}, 3 \mathrm{~h}$ & 1190.00 & Avelar et al. (2010) \\
\hline Eucalyptus sp. & $800^{\circ} \mathrm{C}, 4 \mathrm{~h}$ & $\mathrm{CO}_{2}, 800^{\circ} \mathrm{C}, 4 \mathrm{~h}$ & 1034.07 & Grima-Olmedo et al. (2016) \\
\hline Black wattle & - & $\mathrm{H}_{3} \mathrm{PO}_{4}, 500{ }^{\circ} \mathrm{C}, 2 \mathrm{~h}$ & 905.68 & Linhares et al. (2016) \\
\hline Piassava & - & $\mathrm{H}_{3} \mathrm{PO}_{4}, 500{ }^{\circ} \mathrm{C}, 3 \mathrm{~h}$ & 747.00 & Avelar et al. (2010) \\
\hline Rubber tree & - & $\mathrm{H}_{3} \mathrm{PO}_{4}, 800{ }^{\circ} \mathrm{C}, 4 \mathrm{~h}$ & 693.00 & Thubsuang et al. (2017) \\
\hline Water hyacinth & - & $\mathrm{ZnCl}_{2}, 700^{\circ} \mathrm{C}, 1 \mathrm{~h}$ & 640.00 & Barbosa et al. (2014) \\
\hline Eucalyptus sp. & - & $\mathrm{K}_{2} \mathrm{CO}_{3}, 500{ }^{\circ} \mathrm{C}, 3 \mathrm{~h}$ & 539.00 & Couto et al. (2012) \\
\hline Carnauba palm & - & $\mathrm{CaCl}_{2}, 500^{\circ} \mathrm{C}, 1 \mathrm{~h}$ & 430.69 & Lacerda et al. (2015) \\
\hline Stone pine & - & $\mathrm{H}_{3} \mathrm{PO}_{4}, 500{ }^{\circ} \mathrm{C}, 1 \mathrm{~h}$ & 296.01 & Lacerda et al. (2015) \\
\hline
\end{tabular}

It can be noted that the $\mathrm{H}_{3} \mathrm{PO}_{4} / \mathrm{H}_{2} \mathrm{O}$ AC presented a relatively high surface area when compared to the $\mathrm{S}_{\mathrm{BET}}$ values in the literature, which varies from 296.01 to $1896.00 \mathrm{~m}^{2} \cdot \mathrm{g}^{-1}$. This performance has great 
influence in the adsorption because, usually, a greater surface area mean elevated contaminant adsorption capacity, with the $\mathrm{S}_{\mathrm{BET}}$ as an important aspect to be used for selecting the adsorbents (activated carbon) in contaminant separation processes (BARBOSA et al., 2014).

The $\mathrm{H}_{3} \mathrm{PO}_{4} / \mathrm{H}_{2} \mathrm{O}$ AC $\mathrm{S}_{\mathrm{BET}}$ was inferior to the ones obtained by the bamboo in the works of Hameed, Din and Ahmad (2007) and Hameed and El-Khaiary (2008). That happened because of the changes in the AC production process in this work, which used a direct simultaneous physicochemical activation process, where the carbonization and activation stages occurred simultaneously, possibly resulting in lower production costs for $\mathrm{AC}$ and keeping a $\mathrm{S}_{\mathrm{BET}}>1000 \mathrm{~m}^{2} \cdot \mathrm{g}^{-1}$.

It has to be said that the development of the porous structure of the $\mathrm{AC}$ depends on the used activation process (ABBAS; KADDOUR; TRARI, 2014) and that the simultaneous activation promotes a higher increment in pores and consequently in surface area (HAMEED; El-KHAIARY, 2008), as observed.

Also, the higher the residence time, and activation temperature employed in the process, more elevated will be the AC production costs and the possible damage to the oven. In this scenario, trying to reduce the costs, the residence time $(1 \mathrm{~h})$ and activation temperature $\left(500{ }^{\circ} \mathrm{C}\right)$ used were lower than the literature. Studies on the residence time and activation temperature are extremely important in the energetic viability because higher temperatures demands a higher energy cost and, depending on the objective for the application of the material, the activation can become unfeasible (BORGES et al., 2016).

When we relate the obtained $\mathrm{S}_{\mathrm{BET}}$ in this study with the established improvements in the process, it can be concluded that the $\mathrm{H}_{3} \mathrm{PO}_{4} / \mathrm{H}_{2} \mathrm{O}$ AC is an adsorbent that can be obtained certainly at a low cost.

\section{Effect of the contact time}

This experiment was made intending to evaluate the effect of the initial methylene blue concentration $\left(\mathrm{C}_{0}=50 \mathrm{mg} \cdot \mathrm{L}^{-1}\right)$ due to the adsorbate/adsorbent contact time at room temperature. A vertiginous dye adsorption was observed until the $6 \mathrm{~h}$ time interval and after this period a milder adsorption. The necessary time to reach the adsorption equilibrium was $12 \mathrm{~h}\left(\mathrm{q}_{\mathrm{t}}=49.85 \mathrm{mg} \cdot \mathrm{g}^{-1}\right)$ and the adsorbed dye amount, $\mathrm{q}_{\mathrm{t}}$, was elevated within the adsorbate/adsorbent contact time. Within $24 \mathrm{~h}$ of reaction, the AC had absorbed almost all the dye present in the initial solution (Figure 3).

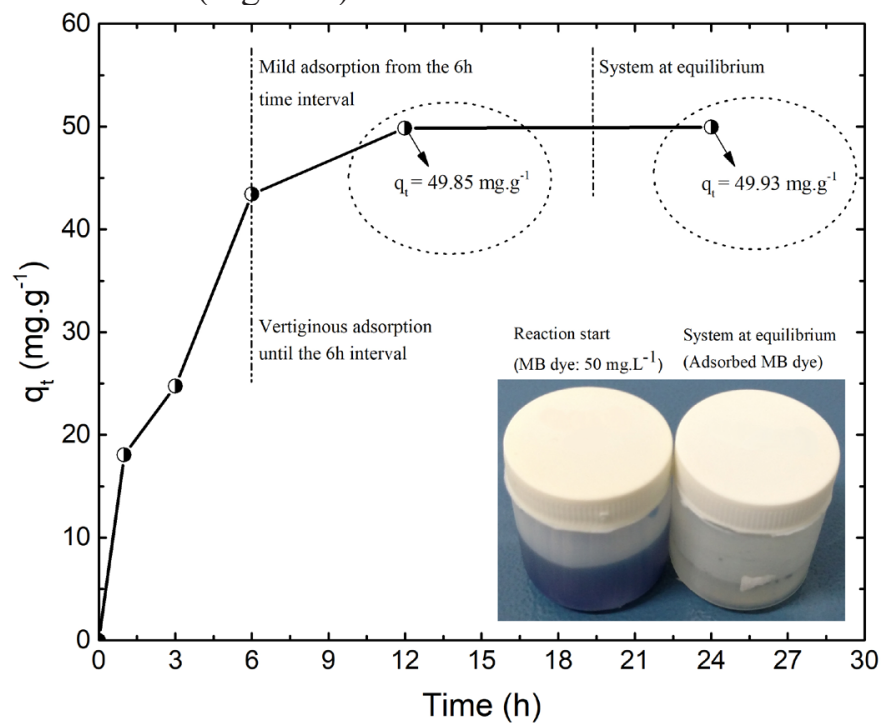

FIGURE 3: Effect of contact time on the initial MB dye concentration (10 mg AC; $10 \mathrm{~mL} 50 \mathrm{mg} . \mathrm{L}^{-1}$ solution; $\mathrm{q}_{\mathrm{t}}=$ amount of adsorbed dye in a t time; at room temperature).

FIGURA 3: Efeito do tempo de contato sobre a concentração inicial do corante AM (10 mg de CA; $10 \mathrm{~mL}$ de solução $50 \mathrm{mg} \mathrm{L}^{-1} ; \mathrm{q}_{\mathrm{t}}=$ quantidade de corante adsorvido no tempo $\mathrm{t}$; em temperatura ambiente). 
A great number of the AC active site were empty in the initial adsorption stages, resulting in a faster adsorption. Within time, the competition for the $\mathrm{AC}$ active sites is softened, delaying the adsorption (ISLAM et al., 2015). The percentage of MB dye removal, R(\%), was obtained according to Eq. (4).

$$
R(\%)_{t}=\frac{\left(C_{0}-C_{t}\right)}{C_{0}} \times 100
$$

where: $\mathrm{C}_{0}$ and $\mathrm{C}_{\mathrm{t}}$ represent respectively the liquid phase concentrations of the dye, initial an at the predetermine time intervals $\left(\mathrm{mg} \cdot \mathrm{L}^{-1}\right)$.

It can be observed that the $\mathrm{H}_{3} \mathrm{PO}_{4} / \mathrm{H}_{2} \mathrm{O}$ AC provided, in $3 \mathrm{~h}$, a percentage of dye removal next to $50 \%$, which confirms the fast filling of its active sites. In addition, within $12 \mathrm{~h}$ of reaction time, the $\mathrm{H}_{3} \mathrm{PO}_{4} /$ $\mathrm{H}_{2} \mathrm{O}$ AC had already removed nearly $100 \%$ of the dye (Table 2 ).

TABLE 2: Methylene blue dye removal percentage at room temperature.

TABELA 2: Percentual de remoção do corante azul de metileno em temperatura ambiente.

\begin{tabular}{cc}
\hline Time (h) & Removal (\%) \\
\hline 1 & 36.09 \\
3 & 49.52 \\
6 & 86.84 \\
12 & 99.70 \\
24 & 99.86 \\
\hline
\end{tabular}

\section{Adsorption isotherm and applied models}

Adsorption isotherms are basic requisites for understanding the adsorption process and indicate how the adsorbate is distribute between the liquid and solid phases when the process reaches equilibrium (HAMEED; DIN; AHMAD, 2007; MEZOHEGYI et al., 2012). The isotherm presented in this work was obtained when considering the relation between the equilibrium concentration $\left(\mathrm{C}_{\mathrm{eq}}\right)$ and adsorbate amount adsorbed by the $\mathrm{AC}\left(\mathrm{q}_{\mathrm{eq}}\right)$ (Figure 4). It was verified that it presented, initially, an increase in the adsorption, indicating an affinity between the adsorbate/adsorbent, followed by a plateau formation that constitutes the maximum saturation capacity, which happens because of the better adjustment to the Langmuir isotherm (DOTTO et al., 2011). 


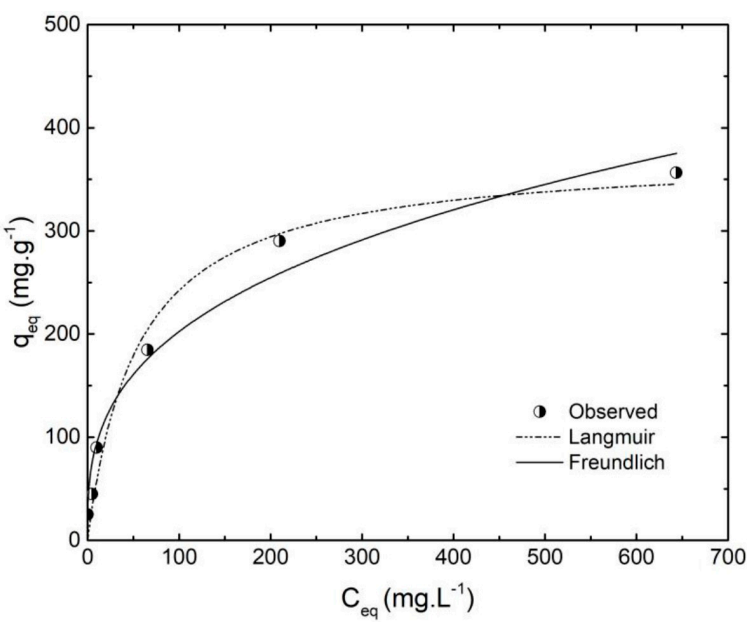

FIGURE 4: Adsorption isotherm for $\mathrm{MB}\left(10 \mathrm{mg} \mathrm{AC} ; 10 \mathrm{~mL}\right.$ different concentrations solutions; $\mathrm{q}_{\mathrm{eq}}=$ amount of adsorbed $\mathrm{MB} ; \mathrm{C}_{\mathrm{eq}}=$ equilibrium concentration; at room temperature).

FIGURA 4: Isoterma de adsorção para o $\mathrm{AM}(10 \mathrm{mg}$ de $\mathrm{CA} ; 10 \mathrm{~mL}$ de soluções em diferentes concentrações; $\mathrm{q}_{\mathrm{eq}}=$ quantidade de $\mathrm{AM}$ adsorvida; $\mathrm{C}_{\mathrm{eq}}=$ concentração de equilíbrio; em temperatura ambiente).

The Langmuir and Freundlich models are usually applied in adsorption studies. The Langmuir model, with better adjustment in this work, assumes the formation of a dye monolayer in the surface of $\mathrm{AC}$, in which all of the sites are identical and energetically equivalents, while the Freundlich estimates that the adsorption happens in heterogenic and not specified sites of the AC (BARBOSA et al., 2014).

\section{Langmuir isotherm model}

The linearized form of the Langmuir is described according to the Eq. (5) and the Langmuir parameter values, calculated by linear regression, are presented in Table 3.

$\frac{C_{e q}}{q_{e q}}=\frac{1}{q_{m} \times K_{L}}+\frac{1}{q_{m}} \times C_{e q}$

where: $\mathrm{q}_{\mathrm{eq}}$ represents the $\mathrm{MB}$ adsorbed quantity $\left(\mathrm{mg} \cdot \mathrm{g}^{-1}\right)$ at a given concentration; $\mathrm{C}_{\mathrm{eq}}$ the concentration of $\mathrm{MB}$ after the equilibrium is reached (mg. $\mathrm{L}^{-1}$ ); and $\mathrm{q}_{\mathrm{m}}$ and $\mathrm{K}_{\mathrm{L}}$ are the parameters associated to the maximum adsorption capacity of the $\mathrm{H}_{3} \mathrm{PO}_{4} / \mathrm{H}_{2} \mathrm{O} \mathrm{AC}\left(\mathrm{mg} \cdot \mathrm{g}^{-1}\right)$ and the Langmuir constant $\left(\mathrm{L} \cdot \mathrm{mg}^{-1}\right)$, respectively.

TABLE 3: Adsorption parameters obtained from the data adjustment to the Langmuir and Freundlich isotherm models for the methylene blue dye at room temperature.

TABELA 3: Parâmetros de adsorção obtidos a partir do ajuste dos dados aos modelos de isoterma de Langmuir e de Freundlich para o corante azul de metileno em temperatura ambiente.

\begin{tabular}{cccc}
\hline \multicolumn{2}{c}{ Langmuir Parameters } & \multicolumn{2}{c}{ Freundlich parameters } \\
\hline $\mathrm{q}_{\mathrm{m}}\left(\mathrm{mg} \cdot \mathrm{g}^{-1}\right)$ & 374.755 & $\mathrm{~N}$ & 3.021 \\
$\mathrm{~K}_{\mathrm{L}}\left(\mathrm{L} \cdot \mathrm{mg}^{-1}\right)$ & 0.018 & $1 / \mathrm{n}$ & 0.331 \\
$\mathrm{R}_{\mathrm{L}}$ & 0.052 & $\mathrm{~K}_{\mathrm{F}}\left[\left(\mathrm{mg} \cdot \mathrm{L}^{-1}\right)\left(\mathrm{L} \cdot \mathrm{mg}^{-1}\right)^{1 / n}\right]$ & 43.985 \\
$\mathrm{R}^{2}$ & 0.968 & $\mathrm{R}^{2}$ & 0.955 \\
\hline
\end{tabular}

Where: $\mathrm{q}_{\mathrm{m}}=$ maximum adsorption capacity $\left(\mathrm{mg} . \mathrm{g}^{-1}\right) ; \mathrm{K}_{\mathrm{L}}=$ Langmuir constant; $\mathrm{R}_{\mathrm{L}}=$ Dimensionless equilibrium parameter; $\mathrm{R}^{2}=$ Correlation coefficient; $1 / \mathrm{n}=$ Sorption intensity measure; $\mathrm{K}_{\mathrm{F}}=$ Sorption coefficient. 
The maximum adsorption capacity $\left(\mathrm{q}_{\mathrm{m}}\right)$ obtained for the $\mathrm{MB}$ dye in this work was $374.75 \mathrm{mg} \cdot \mathrm{g}^{-1}$ and is in accordance to the maximum values presented in the adsorption isotherms (as show in Figure 4). The $\mathrm{q}_{\mathrm{m}}$ value allows to evaluate the adsorption capacity by identifying the AC capacity to retain a certain solute, which can be used to estimate the extension of the movement in the liquid phase. Therefore, this parameter can be understood as a measure of the equilibrium distribution between the solid and liquid phases; the higher the adsorptive capacity of the AC, the higher the obtained $\mathrm{q}_{\mathrm{m}}$ value (BORGES et al., 2016). The favorable nature of adsorption could be expressed in terms of a dimensionless equilibrium parameter, $\mathrm{R}_{\mathrm{L}}$, according to the Eq. (6) and the expressed value of $\mathrm{R}_{\mathrm{L}}$ can be of an irreversible nature $\left(\mathrm{R}_{\mathrm{L}}=\right.$ 0 ), favorable $\left(0<R_{\mathrm{r}}<1\right)$, linear $\left(\mathrm{R}_{\mathrm{r}}=1\right)$ or unfavorable $\left(\mathrm{R}_{\mathrm{r}}>1\right)$ (ABBAS; KADDOUR; TRARI, 2014).

$$
R_{L}=\frac{1}{1+K_{L} \times C_{0}}
$$

where: $\mathrm{K}_{\mathrm{L}}$ is the Langmuir constant and $\mathrm{C}_{0}$ the initial dye concentration in the higher analyzed one.

Thus, the obtained $\mathrm{R}_{\mathrm{L}}$ value was 0.052 , which proves that the adsorption process of the methylene blue dye by the $\mathrm{H}_{3} \mathrm{PO}_{4} / \mathrm{H}_{2} \mathrm{O}$ AC was of a favorable nature.

\section{Freundlich isotherm model}

The linearized form of the Freundlich isotherm model is described according to the Eq. (7) and the calculated values of the Freundlich presented in Table 3.

$$
\log q_{e q}=\log K_{F}+\frac{1}{n} \log C_{e q}
$$

where: $\mathrm{q}_{\mathrm{eq}}$ represents the amount of adsorbed $\mathrm{MB}\left(\mathrm{mg} \cdot \mathrm{g}^{-1}\right)$ at a given concentration; $\mathrm{C}_{\mathrm{eq}}$ the $\mathrm{MB}$ concentration after the equilibrium is reached (mg. $\mathrm{L}^{-1}$ ); and $\mathrm{K}_{\mathrm{F}}$ and $1 / \mathrm{n}$ are the parameters associated to the $\mathrm{H}_{3} \mathrm{PO}_{4} / \mathrm{H}_{2} \mathrm{O}$ AC adsorption parameter $\left[\left(\mathrm{mg}^{-\mathrm{L}^{-1}}\right)\left(\mathrm{L} \cdot \mathrm{mg}^{-1}\right)^{1 / \mathrm{n}}\right]$ and the sorption intensity, respectively (ROCHA el al., 2012).

The adjustment of the observed data to the employed isotherm happened bearing in mind the $\mathrm{R}^{2}$ values obtained in the Langmuir and Freundlich parameters. Thus, the $\mathrm{R}^{2}$ values (Table 3 ) confirm that the Langmuir isotherm model presented a better adjustment to the analyzed data $\left(\mathrm{R}^{2}=0.968\right)$ than the one acquired by Freundlich model $\left(\mathrm{R}^{2}=0.955\right)$. This scenario shows that the adsorption happened in homogeneous and specific active sites of $\mathrm{H}_{3} \mathrm{PO}_{4} / \mathrm{H}_{2} \mathrm{O}$ AC, indicating that the adsorption was of a chemical nature (DOTTO et al., 2011).

The $\mathrm{N}$ exponent accuses if the isotherm is favorable or unfavorable related to the Freundlich model, with the value of $\mathrm{n}$, in the 1 to 10 interval, expressive of favorable adsorption conditions, which are also related to the scale of adsorbate/adsorbent iteration (ROCHA et al., 2012). The $\mathrm{N}$ reached value was 3.021 (Table 3), which shows that the method analyzed for the MB dye was of a favorable nature. However, it can be noticed that the $\mathrm{R}^{2}$ value was 0.955 , proving that the Langmuir model worked better to the data highlighted in this study. 


\section{Fraction of dye accessible porosity}

The surface area estimated from the adsorption of the MB dye was calculated according to the Eq. (8) and the obtained value was $723.28 \mathrm{~m}^{2} \cdot \mathrm{g}^{-1}$. The $\mathrm{S}_{\mathrm{MB}} / \mathrm{S}_{\mathrm{BET}}$ relation is an indication of the accessible porosity fraction to the MB dye (BRUM et al., 2008). In this study, the relation was 0.53 , which indicates that the MB molecules occupy near to $53 \%$ of the total porosity found to the $\mathrm{S}_{\mathrm{RF}}$ of the $\mathrm{H}_{2} \mathrm{PO}_{4} / \mathrm{H}_{2} \mathrm{O} A C$.

$$
S_{M B}=1000 \times S_{M B}^{\mathrm{o}} \times q_{m}
$$

where: $\mathrm{S}_{\mathrm{MB}}=$ surface area estimated by the $\mathrm{MB}$ index $\left(\mathrm{m}^{2} \cdot \mathrm{g}^{-1}\right) ; \mathrm{S}_{\mathrm{MB}}^{\mathrm{o}}=$ surface area of the $\mathrm{MB}$ dye $\left(\mathrm{S}_{\mathrm{MB}}^{\mathrm{o}}=1.93 \mathrm{~m}^{2} \cdot \mathrm{g}^{-1}\right)$; and $\mathrm{q}_{\mathrm{m}}=$ maximum $\mathrm{MB}$ adsorbed capacity $\left(\mathrm{mg} \cdot \mathrm{g}^{-1}\right)$ obtained by the produced $\mathrm{AC}$.

\section{Adsorption of methylene blue dye obtained for other adsorbents}

The adsorption using AC is an efficient and economic process (ABBAS; KADDOUR; TRARI, 2014). The maximum adsorption capacity, $\mathrm{q}_{\mathrm{m}}$, obtained for the methylene blue by the $\mathrm{H}_{3} \mathrm{PO}_{4} / \mathrm{H}_{2} \mathrm{O} A C$, in comparison to other available adsorbents in the literature, are demonstrated in the Table 4.

TABLE 4: Maximum adsorption capacity $\left(\mathrm{q}_{\mathrm{m}}\right)$ of methylene blue obtained for various adsorbents. TABELA 4: Capacidade máxima de adsorção $\left(\mathrm{q}_{\mathrm{m}}\right)$ do azul de metileno obtida por vários adsorventes.

\begin{tabular}{ccccc}
\hline Raw material & Activating agent & $\mathrm{m} / \mathrm{m}$ & $\mathrm{q}_{\mathrm{m}}$ (mg.g $\left.\mathrm{m}^{-1}\right)$ & Reference \\
\hline Bamboo & $\mathrm{H}_{3} \mathrm{PO}_{4} / \mathrm{H}_{2} \mathrm{O}$ & $2: 1$ & 374.75 & This work \\
Bamboo & $\mathrm{KOH} / \mathrm{CO}_{2}$ & $1: 1$ & 454.20 & Hameed et al. (2007) \\
Rattan & $\mathrm{NaOH}$ & - & 359.00 & Islam et al (2017) \\
Piassava & $\mathrm{ZnCl}_{2}$ & $1: 1$ & 276.40 & Avelar et al. (2010) \\
Buriti & $\mathrm{ZnCl}_{2}$ & $1: 3$ & 274.62 & Pezoti Jr et al. (2014) \\
Piassava & $\mathrm{H}_{3} \mathrm{PO}_{4}$ & $1: 1$ & 239.12 & Avelar et al. (2010) \\
Cocoa & $\mathrm{CO}_{2}$ & - & 212.77 & Ahmad et al. (2012) \\
Coffee & $\mathrm{ZnCl}_{2}$ & $1: 1$ & 188.70 & Brum et al. (2008) \\
Eucalyptus sp. & $\mathrm{K}_{2} \mathrm{CO}_{3}$ & $1: 1$ & 81.00 & Couto et al. (2012) \\
Candeia & $\mathrm{CO}_{2}$ & - & 16.10 & Borges et al. (2016) \\
\hline
\end{tabular}

Where: $\mathrm{m} / \mathrm{m}=$ proportion of raw material used $(\mathrm{g}) /$ activating chemical agent $(\mathrm{g})$.

Literature shows that the value of $\mathrm{q}_{\mathrm{m}}$ at essays of adsorption equilibrium for $\mathrm{MB}$ dye by various adsorbents can vary from 16.10 to $454.20 \mathrm{mg} \cdot \mathrm{g}^{-1}$. Thus, it can be said that the $\mathrm{H}_{3} \mathrm{PO}_{4} / \mathrm{H}_{2} \mathrm{O}$ AC can be an excellent adsorbent for dye adsorbing in an aqueous medium, which has been an environment problem. Also, as already described, this result is related to the relatively high value obtained in the $\mathrm{S}_{\mathrm{BET}}$ analysis (see Table 1) that has great influence with the $\mathrm{q}_{\mathrm{m}}$ elevation. 
According to Abbas, Kaddour and Trari (2014), the differences in the adsorption values are related to the proprieties of each adsorbent, like structure, functional groups and porosity. In addition to those, Mezohegyi et al. (2012) notes several other factors that includes the interaction between the adsorbate and adsorbent, the surface chemical, the dye molecule characteristics, $\mathrm{pH}$, temperature and contact time.

The comparison of the obtained $\mathrm{q}_{\mathrm{m}}$ value of synthetized AC with other adsorbents show that its economic and industrial interest (ABBAS; KADDOUR; TRARI, 2014), mainly when considering the amount of chemical activating agent used in the process was cut in half for this study $(\mathrm{m} / \mathrm{m}=2: 1)$.

\section{CONCLUSIONS}

The quality and certainly low cost $\mathrm{AC}$ production was demonstrated in this study using the bamboo as a raw material. The $\mathrm{H}_{3} \mathrm{PO}_{4} / \mathrm{H}_{2} \mathrm{O}$ AC presented a considerably elevated $\mathrm{S}_{\mathrm{BET}}$ when compared to the $\mathrm{S}_{\mathrm{BET}}$ values presented in the literature that varies on the 296.01 to $1896.00 \mathrm{~m}^{2} \cdot \mathrm{g}^{-1}$ range.

The produced $\mathrm{AC}$ was efficient in removing the methylene blue dye, presenting a quick adsorption and high adsorption capacity $\left(374.75 \mathrm{mg}^{-1} \mathrm{~g}^{-1}\right.$. The results obtained in this study recommend the use of the $\mathrm{AC}_{3} \mathrm{PO}_{4} / \mathrm{H}_{2} \mathrm{O}$ in the treatment of the water contaminated by methylene blue dye, foremost in higher concentrations than limits admitted by the legislation.

\section{REFERENCES}

ABBAS, M.; KADDOUR, S.; TRARI, M. Kinetic and equilibrium studies of cobalt adsorption on apricot stone activated carbon. Journal of Industrial and Engineering Chemistry, Washington, v. 20, p. 745751, 2014.

AHMAD, F. et al. Cocoa (Theobroma cacao) shell-based activated carbon by $\mathrm{CO}_{2}$ activation in removing of Cationic dye from aqueous solution: Kinetics and equilibrium studies. Chemical engineering research and design, [s.1], v. 90, n. 10, p. 1480-1490, 2012.

AVELAR, F. F. et al. The use of piassava fibers (Attalea funifera) in the preparation of activated carbon. Bioresource Technology, Essex, v. 101, n. 12, p. 4639-4645, 2010.

BARBOSA, C. S. et al. Remoção de compostos fenólicos de soluções aquosas utilizando carvão ativado preparado a partir do aguapé (Eichhornia crassipes): estudo cinético e de equilíbrio termodinâmico. Química Nova, São Paulo, v. 37, n. 3, p. 447-453, 2014.

BORGES, W. M. S. et al. Produção, caracterização e avaliação da capacidade adsortiva de carvões ativado em forma de briquete. Revista Matéria, Rio de Janeiro, v. 21, n. 4, p. 930-942, 2016.

BRUM, S. S. et al. Preparação e caracterização de carvão ativado produzido a partir de resíduos do beneficiamento do café. Química Nova, São Paulo, v. 31, n. 5, p. 1048-1052, 2008.

BULUT, Y.; AYDIN, H. A kinetics and thermodynamics study of methylene blue adsorption on wheat shells. Desalination, Amsterdam, v. 194, n. 1, p. 259 - 267, 2006.

CARMEN, Z.; DANIELA, S. Textile organic dyes-characteristics, polluting effects and separation/ elimination procedures from industrial effluents-a critical overview. In: PUZYN, T.; MOSTRAGSZLICHTYNG, A. Organic pollutants ten years after the Stockholm convention-environmental and analytical update. Croatia: InTech, 2012. p. 55-81.

CESKAA. Global Activated Carbon Market: 2016-2021. Madison: CESKAA, 2016. Available from: $<$ http://www.ceskaa.com/>. Accessed in: 18 maio 2016.

COUTO, G. M. et al. Use of sawdust Eucalyptus sp. in the preparation of activated carbons. Ciência e Agrotecnologia, Lavras, v. 36, n. 1, p. 69-77, 2012. 
DOTTO, G. L. et al. Remoção dos corantes azul brilhante, amarelo crepúsculo e amarelo tartrazina de soluções aquosas utilizando carvão ativado, terra ativada, terra diatomácea, quitina e quitosana: estudos de equilíbrio e termodinâmica. Química Nova, São Paulo, v. 34, n. 7, p. 1193-1199, 2011.

GRIMA-OLMEDO, C. et al. Activated carbon from flash pyrolysis of eucalyptus residue. Heliyon, London, v. 2, n. 9, p. e00155, 2016.

HAMEED, B. H.; DIN, A. T. M.; AHMAD, A. L. Adsorption of methylene blue onto bamboo-based activated carbon: Kinetics and equilibrium studies. Journal of Hazardous Materials, Amsterdam, v. 141, p. 819-825, 2007.

HAMEED, B. H.; EL-KHAIARY, M. I. Equilibrium, kinetics and mechanism of malachite green adsorption on activated carbon prepared from bamboo by $\mathrm{K}_{2} \mathrm{CO}_{3}$ activation and subsequent gasification with $\mathrm{CO}_{2}$. Journal of Hazardous Materials, Amsterdam, v. 157, p. 344-351, 2008.

HAYASHI, J. et al. Preparing activated carbon from various nutshells by chemical activation with $\mathrm{K}_{2} \mathrm{CO}_{3}$. Carbon, New York, v. 40, p. 2381-2386, 2002.

ISLAM, M. A. et al. Methylene blue adsorption on factory-rejected tea activated carbon prepared by conjunction of hydrothermal carbonization and sodium hydroxide activation processes. Journal of the Taiwan Institute of Chemical Engineers, Taiwan, v. 52, p. 57-64, 2015.

ISLAM, M. A. et al. Mesoporous activated carbon prepared from $\mathrm{NaOH}$ activation of rattan (Lacosperma secundiflorum) hydrochar for methylene blue removal. Ecotoxicology and environmental safety, United States, v. 138, p. 279-285, 2017.

LINHARES, F. A.; MARCÍLIO, N. R.; MELO, P. J. Estudo da produção de carvão ativado a partir do resíduo de casca da acácia negra com e sem ativação química. Scientia cum Industria, Caxias do Sul, v. 4, n. 2, p. 74-79, 2016.

MEDEIROS, L. L. Remoção de cobre (II) de soluções aquosas por carvões ativados de bagaço de canade-açúcar e endocarpo de coco da baía isentos de tratamentos químicos superficiais. 2008. 99 f. Tese (Doutorado em Química Analítica) - Universidade Federal da Paraíba, João Pessoa, 2008.

MEZOHEGYI, G. et al. Towards advanced aqueous dye removal processes: a short review on the versatile role of activated carbon. Journal of Environmental Management, United States, v. 102, n. 15, p. 148-164, 2012.

NAÇÕES UNIDAS. Quase metade da população mundial viverá em áreas com grande escassez de água até 2030. 2016. Available from: <https://nacoesunidas.org/quase-metade-da-populacao-mundialvivera-em-areas-com-grande-escassez-de-agua-ate-2030-alerta-onu/>. Accessed in: 10 set. 2016.

NJOKU, V. O. et al. Preparation of activated carbons from rambutan (Nephelium lappaceum) peel by microwave-induced $\mathrm{KOH}$ activation for acid yellow 17 dye adsorption. Chemical Engineering Journal, Lausanne, v. 250, p. 198-204, 2014.

NJOKU, V. O.; FOO, K. Y.; HAMEED, B. H. Microwave-assisted preparation of pumpkin seed hull activated carbon and its application for the adsorptive removal of 2,4-dichlorophenoxyacetic acid. Chemical Engineering journal, Lausanne, v. 215, p. 383-388, 2013.

PEZOTI JR, O. et al. Adsorption studies of methylene blue onto $\mathrm{ZnCl} 2$-activated carbon produced from buriti shells (Mauritia flexuosa L.). Journal of industrial and engineering chemistry, South Korea, v. 20, n. 6, p. 4401-4407, 2014.

PEZOTI JR, O. et al. NaOH-activated carbon of high surface area produced from guava seeds as a high-efficiency adsorbent for amoxicillin removal: Kinetic, isotherm and thermodynamic studies. Chemical Engineering Journal, Lausanne, v. 288, p. 778-788, 2016.

ROCHA, O. R. S. et al. Avaliação do processo adsortivo utilizando mesocarpo de coco verde para remoção do corante cinza reativo BF-2R. Química Nova, São Paulo, v. 35, n. 7, p. 1369-1374, 2012.

ROMERO-ANAYA, A. J. et al. Spherical carbons: Synthesis, characterization and activation processes. Carbon, New York, v. 68, p. 296-307, 2014.

SANTANA, G. M. et al. Development of activated carbon from bamboo (Bambusa vulgaris) for pesticide 
removal from aqueous solutions. Cerne, Lavras, v. 23, n. 1, p. 123-132, 2017.

LACERDA, V. S. et al. Rhodamine B removal with activated carbons obtained from lignocellulosic waste. Journal of environmental management, United States, v. 155, p. 67-76, 2015.

SKAAR, C. Wood-water relations. 1. ed. New York: Springer-Verlag, 1988. 283 p.

THUBSUANG, U. et al. Tuning pore characteristics of porous carbon monoliths prepared from rubber wood waste treated with $\mathrm{H}_{3} \mathrm{PO}_{4}$ or $\mathrm{NaOH}$ and their potential as supercapacitor electrode materials. Journal of Materials Science, Netherlands, v. 52, n. 11, p. 6837-6855, 2017. 